irrigation purposes, and will eventually if not at once seriously injure land to which it is applied.

To further prove that land irrigated by the Deer I_odge River contains excessive amounts of copper, samples were taken at various distances from the smelter with the idea of determining in them both soluble and insoluble copper. Several of these have been examined but the results show such excessive amounts of copper that the writer is not willing to publish the results until he has confirmed them by collecting and examining new samples. That considerable quantities of copper are present in this soil, however, is undoubtedly true since the soil along the edges of the irrigation ditches, I2 miles and more below the inlet of the smelter waste into the river, is colored distinctly blue with copper. Further than this, the writer tested the soil on a farm irrigated by the Deer Lodge River water Io to I2 miles below the inlet of the tailings, with his knife blacle and was able to obtain an excellent coat of what afterwards on examination proved to be copper.

Although the results of the examination of the injury to vegetation and animals by the Anaconda Smelter is not completed, from the work already done the following definite conclusions can be drawn.

Ist. The vegetation around the smelter for at least 7 to 8 miles south and 13 to I 5 miles west is seriously injured.

2nd. The Junipers are very resistant to smelter fumes and appear able to grow close to the smelter; the Red Firs are very susceptible to the fumes and are badly damaged at distances of I 3 to I 5 miles from the smelter; Lodge Pole pines are intermediate between the other two species of trees, but show danage for at least io miles.

3rd. Large quantities of arsenic are discharged from the smelter on the surrounding country, being present in forage crops in large enough quantities to poison cattle.

th. The waste from the reduction plant discharged in the Deer Lodge River renclers it unfit for irrigation purposes.

\title{
A PORTABLE PHOTOMETER.
}

BY JAMES A. EVANS.

Received May II, IC̣07.

During the years I9OI and I902 the writer was Gas Inspector for the city of Cleveland, Ohio. During that time it became very urgent to know in concrete numbers what candle power the street lamps were producing, because the contract for street lighting was given on the basis of a definite candle power, with a penalty for falling below the specified standard.

The lamps were mantle burners with glass chimneys and enclosed in glass globes. They were fed by artificial gas and by gasoline. We 
first tried the portable photometers on the market. but they were entirely inadequate. The plan of transporting the lamps to the stationary photoweter in the City. Ilall was tried. but the irail mantles wore broken in transit and gave very erroneous results. I therefore invented the fol1. wring Portable Photometer, which prowed high!! satisactury.

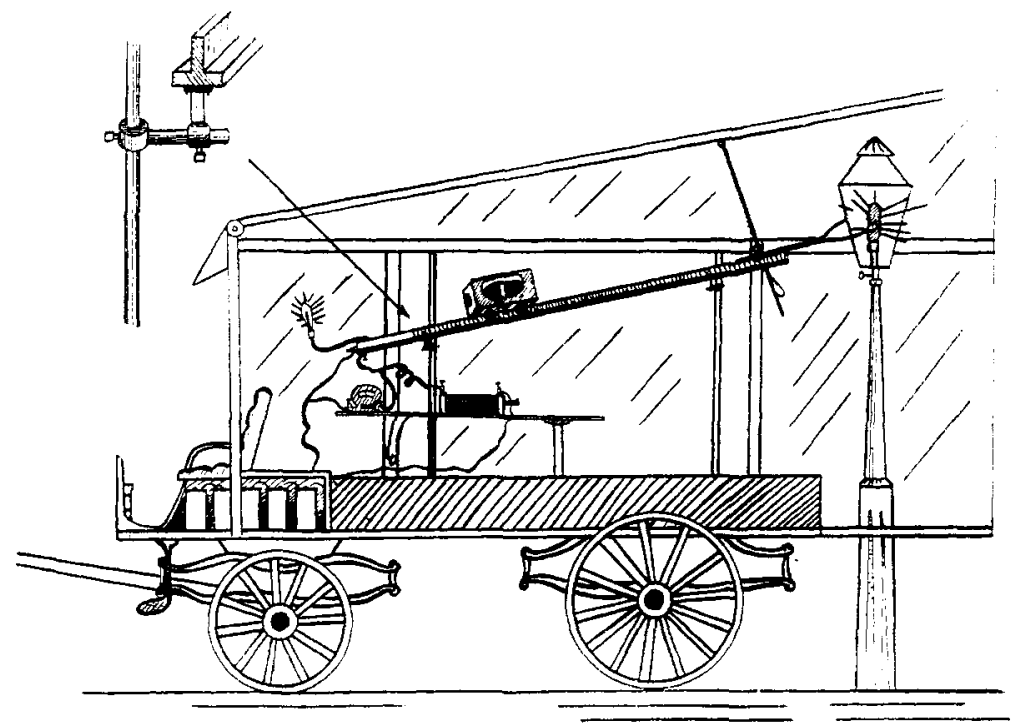

A light spring wagon was secured and an adjustable top built on it. The frame was made of light steel and covered with oilcloth, which was painted a dead black on the inside. thus forming a veritable dark room. The frame work extended about four feet beyond the back end of the wagon, the roof was hung on hinges, at the front end, while the back end conld be raised during operation, to tale in the street lamp. The wagon was backed up to the curb and the lamp enclosed within the extension. A black oilcloth curtain was then drawn across the back. thus completing the dark room. Within the wagon. the photometer bar rested on round steel rods which were, in turn, attached to the upright pieces of the wagon top, giving place for the operator on the floor of the wagon. The bar was held in place by sliding set screws and could be muved out or in and up or down very conveniently and brought into perfect alignment with the light. In the front end of the wagon, under the seat, was a storage battery of 12 cells, with learl plates and dilute sulphuric acid for the electrolyte. An 8 candle power incandescent lamp was attached to the forward end of the bar and connected with the storage battery. In the circuit was a Weston roltmeter and rheo-tat. The lamp was standardized in the laboratory, from time to time, to find the exact voltage required to deliver exactly 8 candle power. and this volt- 
age was held constant when at work by means of the volt meter and rheostat. The bar was of wood and carefully graduated to sixteenths of an inch. Its base served as a track for the Lummer-Brodhun sighting box to run on. The bar was 8 feet long with the electric lamp at zero. The distance from the other end of the bar to the street light was measured by means of a light stick, with a pointer at one end of it and a fork at the other, large enough to span the lamp. Each prong of the fork terminated with a ring with a wire cross-hair stretched across it. This afforded an easy and accurate means of getting the distance from the center of the mantle to the end of the bar, which of course, varied with the different lamps.

The instrument required two men to operate it; one to adjust the bar and take the reading and the other to line up the cross hairs with the mantle and get the distance from the bar. The time required to back up to a lamp, adjust the bar, take the readings and measurements and get away was about seven minutes. The candle power of the lamps for each night's work was figured out afterwards by means of logarithms and a table of squares.

Erie, Pa.

\section{CONTRIBUTIONS TO THE CHEMISTRY OF THALLIUM, II.}

BY L. F. HAWLEY,

Received May 2, 1907.

A Ner Method for the Gratimetric Determination of Thallium. By precipitating and weighing the thallium as thallium sulphostannate, $\mathrm{Tl}_{4} \mathrm{SnS}_{4}{ }^{1}$, a very accurate and easy determination of thallium can be made. The thallium sulphostannate can readily be prepared in pure condition; it is practically insoluble in water so that it can be washed very thoroughly without loss, and it can be dried at $105^{\circ}$ without decomposition. The thallium may be in either the thallous or thallic condition at the time of precipitation since the precipitants will also act as reducing agents. All the elements precipitated by sodium sulphide, including those which are soluble in excess, will interfere with the formation of pure thallium sulphostannate. The reagents required are a solution of primary sodium sulphide with a concentration of about I 50 grams per liter, and a solution of sodium sulphostannate containing only a slight excess of sodium sulphide. This latter solution need not be free from the sodium salts formed in its preparation and can therefore readily be made by adding sodium sulphide solution to a solution of stannic chloride until the precipitate first formed is just dissolved. The procedure for the preparation of the pure thallium sulphostannate is as follows:

To the hot and very slightly acid solution of the thallium salt add an excess of the sodium sulphostannate solution, i. $c$.. more than enough to form

'Hawley, J. Physic. Chem., 10, 654 (1906). 